\title{
Study on the Dynamic Factors of Collaborative Innovation in Cultural and Technological Integration Demonstration Parks
}

\author{
Tianwei Huang, Xiaoqi Li \\ School of Management, Wuhan University of Science and Technology, Wuhan, P.R.China,430081 \\ (E-mail: Lily11010@163.com, m18871191642@163.com)
}

Keywords: Cultural and technological integration demonstration park, collaborative innovation, theory of rent-seeking, dynamic factors.

\begin{abstract}
As a type of cross-industry cluster, the construction of demonstration parks is the integration of social economy, science and technology. The paper introduces the quantitative analysis on the source and mechanism of the dynamic factors of collaborative innovation in demonstration parks and it found that the innovation dynamic mainly originates from four dynamic factors: cultural capacity, political support, talents' capacity and the capital support.
\end{abstract}

\section{Introduction}

The research of the cultural and technological integration demonstration park is still in its initial stage, especially the research on the dynamic factors of the innovation of the park. This paper integrates the reasons of the enterprises needing collaborative innovation in the cluster, the source of the cooperative innovation power of the demonstration park, and perfects the existing system dynamics theory framework. Through the analysis of exploration, to seek the synergy of innovation dynamic factors and mechanism of demonstration parks.

\section{Literature review}

\subsection{The related theoretical basics}

The internal innovative forces include: income driving force, the influence of cluster culture and innovative dynamic. The synergy innovation of research\&development is attributed to internal and external forces. The external forces are composed of technology promotion, market demand and competitive pressure, government's supporting force. And the internal forces are profit driving force, the strategic of synergy guidance force, the internal innovation mechanism dynamic. At present, the source of agglomeration rents is the heterogeneity effect formed by industry agglomeration. However, the cluster rents' continuous declining indicates that it's in the recession period.

\subsection{The assumption of demonstration park collaborative innovation forces}

Based on the previous literature and rent theory, it concludes that synergy innovation forces of the cultural and technological integration demonstration park has following hypothesis: (1) cultural factors: in the process of economic operation, the regional cultural background affects the subject of each economic activity. The cultural connotation of the creative industry is ranked in the first factor, this paper puts forward the following hypotheses: H1: cultural factors play an important role in promoting the synergy of innovation in the demonstration park. (2) policy factors: policy preference is crucial and necessary. Government has responsibility to support the development of new industries. The paper puts forward the following hypotheses: H2: policy factors play an important role in the improvement of collaborative innovation dynamics in demonstration parks; (3) talent factor: the aggregation of demonstration parks is essentially the accumulation of creative talents. This paper puts forward the following hypotheses: H3: talent factors play an important role in improving the synergy of the demonstration park; (4) financial factors: financial support is the most effective factor and puts forward the following hypotheses: H4: financial factors play an crucial role in improving the synergy of demonstration parks. 


\section{Questionnaire and statistic analysis}

\subsection{Source of date}

The evaluation variables of the collaborative innovation forces divided into the 4 dimensions (cultural indicators, policy indicators, talent indicators, financial indicators) and 16 evaluative indicators (shown in table 3.1) were set up. According to the Likert five scale, the quantitative evaluation index is dividing into five intervals by the important degree.

Table 3.1 Evaluation indicators and validity analysis table

\begin{tabular}{|c|c|c|c|c|c|c|c|}
\hline Dimension & $\mathrm{KMO}$ & \multicolumn{2}{|c|}{ Explanation Variance } & \multicolumn{2}{|c|}{ Dimension } & KMO & $\begin{array}{c}\text { Explanation } \\
\text { Variance }\end{array}$ \\
\hline $\begin{array}{l}\text { Cultural } \\
\text { Indicators }\end{array}$ & 0.735 & \multicolumn{2}{|c|}{$79.021 \%$} & \multicolumn{2}{|c|}{ Talent Indicators } & 0.833 & $67.906 \%$ \\
\hline $\begin{array}{l}\text { Long } \\
\text { history of } \\
\text { culture }\end{array}$ & $\begin{array}{l}\text { Rich cultural } \\
\text { resources }\end{array}$ & $\begin{array}{c}\text { Strong } \\
\text { cultural } \\
\text { atmosphere }\end{array}$ & $\begin{array}{l}\text { Complete } \\
\text { facilities }\end{array}$ & $\begin{array}{l}\text { Strong } \\
\text { cultural } \\
\text { culture }\end{array}$ & $\begin{array}{l}\text { University } \\
\text { agglomerati } \\
\text { on }\end{array}$ & $\begin{array}{l}\text { Adequate } \\
\text { supply } \\
\text { of talent }\end{array}$ & $\begin{array}{c}\text { Prosperity of } \\
\text { education }\end{array}$ \\
\hline 0.832 & 0.816 & 0.767 & 0.857 & 0.881 & 0.778 & 0.827 & 0.803 \\
\hline $\begin{array}{c}\text { Policy } \\
\text { Indicators }\end{array}$ & 0.805 & \multicolumn{3}{|c|}{$78.614 \%$} & $\begin{array}{l}\text { Financial } \\
\text { Indicators }\end{array}$ & 0.855 & $73.605 \%$ \\
\hline $\begin{array}{c}\text { Tax } \\
\text { concessions }\end{array}$ & $\begin{array}{l}\text { Public } \\
\text { infrastructure } \\
\text { construction }\end{array}$ & $\begin{array}{c}\text { Government } \\
\text { investment }\end{array}$ & $\begin{array}{c}\text { Financing } \\
\text { support }\end{array}$ & $\begin{array}{c}\text { Knowledge- } \\
\text { oriented } \\
\text { talents } \\
\end{array}$ & $\begin{array}{c}\text { Diversified } \\
\text { financing } \\
\text { Channels } \\
\end{array}$ & $\begin{array}{c}\text { Rich } \\
\text { sources of } \\
\text { funds }\end{array}$ & $\begin{array}{c}\text { Strong } \\
\text { investment } \\
\text { atmosphere } \\
\end{array}$ \\
\hline 0.819 & 0.786 & 0.787 & 0.834 & 0.795 & 0.763 & 0.749 & 0.826 \\
\hline
\end{tabular}

\subsection{Statistical analysis of data}

The survey is hold among management personnel and consumers of demonstration parks. The survey is dividing into two channels: on-line questionnaire websites and interviews questionnaires. Using the Cronbach's alpha measurement in the questionnaire for this study, the resulting coefficient value is 0.723 . The coefficients of the Cronbach's alpha for each sub-item are also above 0.7 (shown in table 3.1 ).

\subsection{Confirmatory factor analysis for dynamic indicators system}

(1) Model identification

Evaluation Index system structured by 4 latent variables, respectively: cultural indicators, policy indicators, talent indicators and financial indicators, in total 16 metrics. Based on the $\mathrm{T}$ principle, $(q+1) / 2=171$, the model has to estimate 16 factor loads, depending on error variance of 16 measurement variables and correlations between the 16 factors, to be estimated parameter values $\mathrm{t}=54<171$, so the model is recognizable.

(2) Evaluation of models

After the model identifying, the path analyzed by the fixed load method and the maximum likelihood estimation method, which verifies whether hypotheses are set up in the evaluation index model. The data in table 3.3 shows the absolute exponent reflected in the fitting index of the model, relative index and the minimalist index is within a reasonable range.

It concluded that the model fitted and the construction validity is good. Therefore, these indicators can be used as a measurement of four potential factors. 


\section{Causal feedback relation analysis of dynamic factors}

Tables 3.2 Confirmatory analysis results

\begin{tabular}{|c|c|c|c|c|c|c|c|c|c|c|}
\hline $\begin{array}{c}\text { Latent } \\
\text { variable }\end{array}$ & Item & $\begin{array}{c}\text { Standardized } \\
\text { coefficients }\end{array}$ & $\begin{array}{c}\mathrm{T} \\
\text { value }\end{array}$ & $\mathrm{R} 2$ & $\begin{array}{c}\text { Latent } \\
\text { variable }\end{array}$ & Item & $\begin{array}{c}\text { Standardized } \\
\text { coefficients }\end{array}$ & $\begin{array}{c}\mathrm{T} \\
\text { value }\end{array}$ & $\mathrm{R} 2$ & Conclusion \\
\hline \multirow{4}{*}{$\begin{array}{l}\text { Cultural } \\
\text { indicators }\end{array}$} & 1 & 0.672 & $\begin{array}{c}10.4 \\
5\end{array}$ & 0.526 & \multirow{5}{*}{$\begin{array}{l}\text { Cultural } \\
\text { indicators }\end{array}$} & 1 & 0.673 & 9.13 & 0.672 & Support \\
\hline & 2 & 0.716 & 8.23 & 0.426 & & 2 & 0.521 & 10.68 & 0.541 & Support \\
\hline & 3 & 0.676 & 8.16 & 0.325 & & 3 & 0.670 & 9.07 & 0.307 & Support \\
\hline & 4 & 0.578 & 8.02 & 0.621 & & 4 & 0.665 & 8.74 & 0.386 & Support \\
\hline \multirow{4}{*}{$\begin{array}{c}\text { Policy } \\
\text { indicators }\end{array}$} & 1 & 0.614 & 9.34 & 0.432 & & 5 & 0.591 & 10.45 & 0.425 & Support \\
\hline & 2 & 0.745 & 8.63 & 0.537 & \multirow{3}{*}{$\begin{array}{l}\text { Financial } \\
\text { indicators }\end{array}$} & 6 & 0.661 & 10.36 & 0.502 & Support \\
\hline & 3 & 0.691 & 9.08 & 0.533 & & 7 & 0.784 & 9.57 & 0.384 & Support \\
\hline & 4 & 0.724 & 10.6 & 0.291 & & 8 & 0.693 & 10.79 & 0.691 & Support \\
\hline
\end{tabular}

Note: $* *$ represents a significant level of $0.05 ; * * *$ represents a significant level of 0.01 .

Tables 3.3 Model fitting goodness test results

\begin{tabular}{|l|l|l|l|l|l|l|l|l|l|l|}
\hline Fitting & X2/df & RMSEA & NFI & NNFI & CFI & IFI & RFI & GFI & AGFI & PGFI \\
\hline results & 2.92 & 0.077 & 0.97 & 0.96 & 0.91 & 0.93 & 0.92 & 0.82 & 0.83 & 0.64 \\
\hline criteria & $\in(2,3)$ & $<0.08$ & $0.9<$ & $0.9<$ & $0.9<$ & $0.9<$ & $0.9<$ & $0.8<$ & $0.8<$ & $0.5<$ \\
\hline
\end{tabular}

Cultural and technological integration demonstration park is affected by a variety of factors, dynamics can be a demonstration park innovation dynamic factors causality feedback diagram. According to the causality feedback graph, the four subsystems and the innovation power respectively constitute the positive feedback cyclic relation. Based on this, the SD Model (shown in figure 4.1) construction assumes the following: (1) the local cultural environment and consumer demand for cultural experience influenced by the innovation dynamics of the park.(2) talent strength influenced by the degree of innovation of cultural products and the innovation power of the park. (3) the impact of capital investment dynamics of the park on factors such as innovation (4) the support of the government is always growing. To sum up, talent factors, capital factors, policy factors, cultural factors of the four dynamic systems must be mutual influence and restriction, each other constraints. The realization of collaborative innovation development of cultural and technological integration demonstration parks must make up of four systems in collaborative approach to promote the innovation and development.

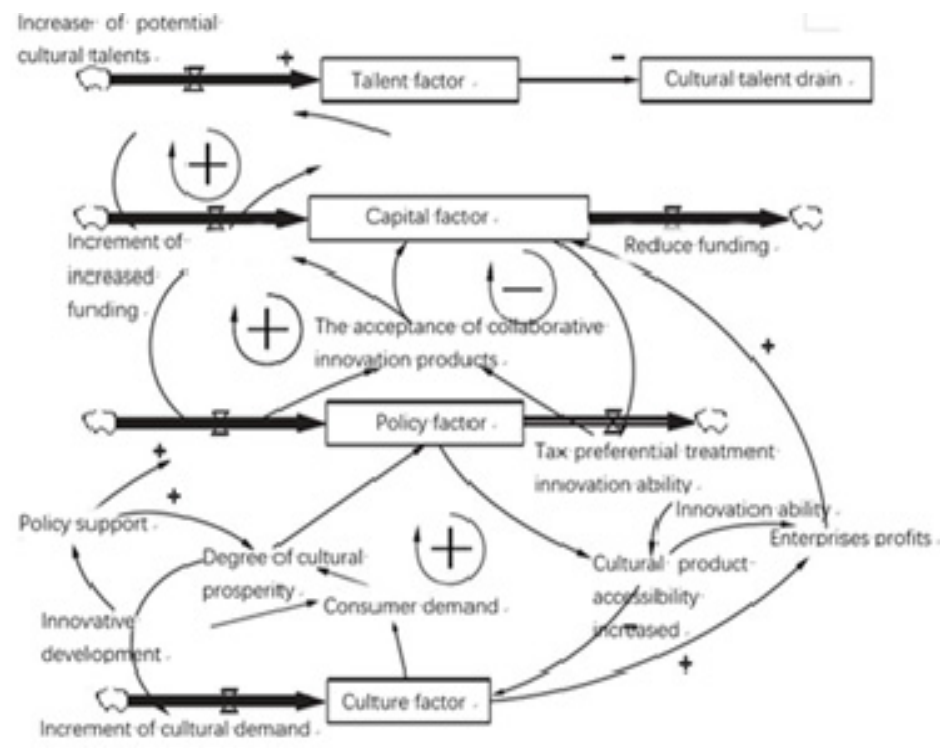

Figure 4.1 SD Model of innovation development 
Center of Wuhan University of Science and Technology(17CYY06).

\section{Acknowledgement}

This research was supported by 'Humanities and Social Science Research Project of Hubei Provincial Department of Education'(18D007); 'The youth of science and technology training program Of WUST'(2016xz042); The general project of center for Industrial Policy and Management Research

\section{References}

[1] Hu Huilin. On the essence of cultural industry. --- rebuilding the cognitive dimension of the cultural industry [J]. Journal of Shandong University, 2017, (03): 001 015

[2] Xie Xuefang. Culture and creative Industry Innovation environment Optimization Research -- - based on the construction of Shanghai Global Science and Technology Innovation Center [J]. Scientific Development, 2015, (9): 54-59

[3] Han Ping, Li Shunbin. Research on the fusion mechanism of culture and science and technology in China- -- based on the High-tech Development Park Angle [M]. Industry Economic Review, 2014, (04): 48-52

[4] Zhong Sheng. The study of government policy innovation in the process of integrating culture with science and technology--taking Wuhan East lake high-tech zone as an example [M]. Scientific and technological progress and countermeasures, 2015, (05): 96 100

[5] Luo Wang, Zeng Tao, Si Wei. Enterprise business model Innovation: explanations based on rent theory[J]. China Industrial Economy, 2015, (7): 31-34

[6] Huang Tianwei. The Research of the Formation Mechanisms of Cultural Creative Industry. Chinese Business Bureau, 2016.

[7]Zhang Changsheng. Research on the dynamic mechanism design of industrial clusters' synergy innovation [J]. Regional Economics, 2015, (3): 18-21

[8]Huang Tianwei. Research on the Calculation Indicator System of the Cultural Creative Industry Cluster Degree, Proceedings-ICIM 2015, 12th International Conference on Innovation and Management, pp.118-121. 